DOI: $10.18276 /$ sip.2016.43/3-04

\title{
Felicjan Bylok*
}

Politechnika Częstochowska

\section{KONSUMPCJA HEDONISTYCZNA A KONSUMPCJA ETYCZNA. CZY POTRZEBNA JEST SPOŁECZNIE ODPOWIEDZIALNA KONSUMPCJA?}

\begin{abstract}
Streszczenie
W artykule przedmiotem refleksji uczyniono relacje między konsumpcją hedonistyczną i konsumpcją etyczną. Autor omawia cechy charakterystyczne konsumpcji hedonistycznej. Wskazuje, że atrakcyjność konsumpcji hedonistycznej opiera się na ujmowaniu szczęścia i przyjemności jako ostatecznych celów konsumpcji, do których należy dążyć. Przedmiotami, które służą osiąganiu tych celów, są dobra konsumpcyjne posiadające ładunek przyjemności i potencjał zapewnienia szczęścia. W artykule wskazano na upowszechnianie się postaw hedonistycznych wśród konsumentów. Następnie autor skupia się na przedstawieniu głównych założeń konsumpcji etycznej. Analizuje jej formy i czynniki determinujące jej występowanie. Podejmuje refleksję nad pojawieniem nowego typu konsumenta - konsumenta społecznie odpowiedzialnego. Omawia jego cechy charakterystyczne oraz przedstawia postulaty dotyczące moralności społecznie odpowiedzialnego konsumenta.
\end{abstract}

Słowa kluczowe: konsumpcja, hedonizm, konsumpcja etyczna, społecznie odpowiedzialna konsumpcja

\section{Wstęp}

Problem skutków nadmiernej konsumpcji jest coraz częściej tematem debat naukowych, jak i praktycznych działań różnego typu organizacji społecznych, które 
zwracają uwagę na zagrożenia wynikającej z ciągle rosnącej konsumpcji. Jedną ze wskazywanych przyczyn wzrostu konsumpcji dóbr jest hedonistyczne podejście ludzi do sfery konsumpcji. Konsumpcję zaczęto postrzegać jako sferę obejmującą fantazje, sensoryczną przyjemność, uczucia i zabawę (Holbrook, Hirschaman, 1982, s. 132). Dzisiaj, kiedy ludzie rozporządzają większą ilością wolnego czasu, większymi pieniędzmi i dostępem do szerokiej palety dóbr konsumpcyjnych, mogą poświęcić się czynnościom, które dostarczają przyjemności bez wyrzutów sumienia.

Analiza badań nad zachowaniami konsumpcyjnymi wskazuje, że konsumenci nabywają produkty i usługi z dwóch podstawowych powodów: utylitarnych i hedonistycznych (Teller, Reutterer, Schnedlitz, 2008; Solomon, 2006). Utylitarne motywy związane są z funkcjonalnym myśleniem zorientowanym na produkt, natomiast hedonistyczne motywy związane są z emocjami ukierunkowanymi na dążenia do przeżywania przyjemności i estetycznych wrażeń w obszarze konsumpcji. Stąd analiza relacji między hedonistycznymi i utylitarnymi zachowaniami konsumentów ma kluczowe znaczenie dla zrozumienia współczesnych zmian w konsumpcji. W badaniu motywów utylitarnych ważne miejsce zajmuje konsumpcja etyczna, a w szczególności społecznie odpowiedzialna konsumpcja. Pojawia się pytanie o zakres występowania zachowań etycznych konsumentów w obszarze konsumpcji. Kluczem do znalezienia odpowiedzi na to pytanie jest analiza stopnia występowania form konsumpcji etycznej i czynników determinujących kształtowanie się społecznie odpowiedzialnego konsumenta.

Celem artykułu jest poszukiwanie odpowiedzi na pytanie: Czy konsumpcja etyczna w zderzeniu z hedonistycznie nastawionymi konsumentami ma perspektywy rozwoju we współczesnym świecie? Do badań wykorzystano systematyczną i porównawczą analizę literatury naukowej z dziedziny konsumpcji hedonistycznej, konsumpcji etycznej i społecznie odpowiedzialnej konsumpcji.

\section{Konsumpcja hedonistyczna}

Pojęcie hedonizmu wywodzi się z nauki greckich filozofów (m.in. Epikura, Lucjusza), dla których centralnym motywem ludzkich działań było dążenie do przyjemności, zabawy i radości. W literaturze poświęconej konsumpcji można spotkać podział hedonizmu na tradycyjny i nowoczesny (Stihler, 2000, s. 172-175). „Tradycyjny” hedonizm oznacza zachowanie ukierunkowane na osiąganie przyjemności dzięki zmysłowej percepcji jako środka stymulowania działania ludzkiego. 
Jednak rozwój tej formy hedonizmu napotkał bariery wynikające z naturalnego ograniczenia ludzkich zmysłów, bowiem sensoryczne odczuwanie przyjemności jest u człowieka relatywnie ograniczone. Z kolei „nowoczesny” hedonizm zwraca się w stronę emocji, które wywołane są przez obraz idealnego stanu przyjemności i rozkoszy związanego z wyimaginowanym użyciem wymarzonego dobra. Produkty, które zawierają w sobie potencjał marzeń, są najbardziej poszukiwane. Jednak po ich nabyciu konsument traci zainteresowanienimi, ponieważ zaczyna marzyć o innych dobrach. Campbell (1987, s. 84) tłumaczy ten proces za pomocą zmodyfikowanego modelu decyzji konsumenckich: tęsknota-zakup - użycie - rozczarowanie. W tym procesie potrzebę zastąpiono tęsknotą (marzeniem), którą trudno zrealizować, ponieważ po zakupie wymarzonego dobra dochodzi do rozdźwięku między marzeniem a rzeczywistością, ponieważ wyobrażenie o idealnym produkcie nie pokrywa się z zakupionym towarem. Pojawia się stan niezadowolenia, który jednak trwa krótko i jest bodźcem do tworzenie nowej konstrukcji marzeń na bazie nowego dobra. Zatem termin hedonizm może być związany zarówno z natychmiastową gratyfikacją, jak i z egoistycznym, indywidualistycznym materializmem połączonym $\mathrm{z}$ ideą nadmiaru i samolubnym zachowaniem (Szmigin, Carrigan, 2005, s. 610).

Typ hedonizmu opisany przez Campbella wpłynął na tworzenie się nowych form konsumpcji - konsumpcji przyjemności i konsumpcji zmysłowej. Istotną składową konsumpcji hedonistycznej jest przyjemność (Alba, Williams, 2012, s. 3). Konsumpcja przyjemności związana jest z dążeniem do przeżywania przyjemności w obszarze konsumpcji. Aby to pożądanie zaspokoić, konsument poszukuje nowych podniet w postaci atrakcyjnych produktów, które stają się środkiem do osiągania przyjemności. Konsument nabywa produkty nie ze względu na ich funkcjonalną wartość, lecz z uwagi na cechy niematerialne, które wpływają na stan odczuwania przyjemności. Mogą to być: smak, zapach, estetyczny wygląd itd. Zawartość niematerialna dóbr zatem staje się ważnym składnikiem subiektywnie odczuwanej jakości życia (Weinberg, 1986, s. 99). Potwierdzają to badania Holbrooka i Hirschman (1982), którzy odkryli, iż w dużej masie konsumenci poszukują dóbr nie ze względu na wartości użytkowe, lecz z uwagi na funkcje zabawowe, tak zwane środki do zabawy, które dostarczają zmysłowych doświadczeń, emocjonalnych impulsów i marzeń. Konsument przyjemności przy podejmowaniu decyzji o zakupie danego produktu zwraca uwagę oprócz ceny (preferując drogie produkty) i prestiżu marki na przyjemną atmosferę podczas zakupów, którą wytwarza obsługa sklepowa (Stihler, 1998, s. 112).

Na zakres konsumpcji przyjemności wpływa orientacja „tu i teraz”, która oznacza, że dobra konsumpcyjne powinny przynieść satysfakcję natychmiast po 
ich nabyciu i zadowolenie powinno się skończyć w chwili, gdy kończy się czas potrzebny do ich skonsumowania. Sens tego nastawienia oddaje motto ,życie należy tutaj i teraz smakować". W konsekwencji takiego nastawienia wiele dóbr jest marnotrawionych, często nowe, nieużywane przedmioty konsumpcji są wyrzucane, aby zrobić miejsce nowościom.

Z kolei konsumpcja zmysłowa związana jest z tak zwanym windows-shopping, w czasie którego materialne obrazy i impresje są konsumowane poprzez narząd wzroku. Konsument idzie pospacerować wśród obiektów konsumpcji ze świata marzeń, które są wystawiane w galeriach, centrach handlowych czy też w domach towarowych, oraz posłuchać, powąchać, posmakować, czyli doświadczyć różnych wrażeń. Staje się postflaneurem, czyli osobą, która odwiedza sklepy w celu doznawania przyjemności z oglądania wystaw sklepowych (Wątroba, 2008, s. 83). Dla tego typu konsumenta funkcje użytkowe produktów są drugorzędne, liczy się tylko „potencjał marzeń” w nich zawarty. Trafnie Bauman (2000, s. 99) określa ten typ konsumentów, pisząc, że „konsumenci są przede wszystkim zbieraczami wrażeń, kolekcjonują rzeczy jedynie wtórnie, jako pochodne doznań".

Konsumpcja hedonistyczna jest związana również z przeżywaniem czegoś ekscytującego, niedostępnego w codziennym życiu. Przy czym niekiedy nawet zaspokajanie potrzeb podstawowych może być motywowane pragnieniem przygody i poprawy nastroju (Arnold, Reynolds, 2003). Przeżycie czegoś niezwykłego zapewnia uczestnictwo w wydarzeniach uznawanych za niezwykłe, na przykład w koncertach gwiazd popkultury czy w festiwalach muzyki rokowej. Wydarzenia takie reklamowane są jako mega, giga, super. Głównym założeniem takich eventów jest wyrobienie wśród konsumentów poczucia, iż uczestniczą w czymś niezwykłym, jedynym w swoim rodzaju, pomimo tego, iż w innym miejscu to samo wydarzenie będzie powtórzone. Niezwykłych przeżyć dostarcza także sfera turystyki, w szczególności podróżowanie w celu poznania świata. To poznawanie świata musi mieć charakter przygody i zaspokajać potrzebę doznawania przyjemności. Taki turysta pełni przede wszystkim rolę konsumenta. Urry (2008, s. 261) uważa, że taki rodzaj mobilności wytwarza własne przestrzenie społeczne, aranżując nowe środki konsumpcji, takie jak stacje, hotele, kurorty, lotniska, kompleksy wypoczynkowe, galerie itd. „Życie w ruchu” staje się stylem życia dla wielu członków rozwiniętych społeczeństw konsumpcyjnych. Turysta nie tylko chce zobaczyć atrakcyjne miejsca i przeżyć przygodę, ale pragnie też odwiedzić centra handlowe i zrobić zakupy.

Atrakcyjność konsumpcji hedonistycznej opiera się na założeniu, że szczęście i przyjemność są ostatecznymi celami, do których należy dążyć. Przedmiotami, 
które służą osiąganiu tych celów, są dobra konsumpcyjne posiadające ładunek przyjemności i potencjał zapewnienia szczęścia. Doznania przyjemności są związane z fizycznymi cechami produktu (jego budową i formą), z poziomem behawioralnym obejmującym użytkowanie produktu i z poziomem refleksyjnym związanym z sensem i interpretacją posiadania danego produktu. Wszystkie trzy poziomy wpływają na doznawanie przyjemności w określony sposób, na przykład podczas użytkowania iPada firmy Apple konsument przyjemność czerpie z jego designu, łatwości użytkowania i uznania go za produkt futurystyczny. Alba i Williams (2012, s. 5-8), analizując konsumpcję hedonistyczną, wskazali na kilka czynników wpływających na stopień doznania przyjemności. Po pierwsze, wpływ ma interakcja konsumenta z produktem; po drugie, stopień zaangażowania z korzystania z produktu - im bardziej konsumenci są zaangażowani, tym większą czerpią przyjemność z tego; po trzecie, oczekiwanie co do tego, że produkt w przyszłości zapewni przyjemność; po czwarte, przekonanie, że konsumpcja produktu przyniesie oczekiwany zakres przyjemności; po piąte, zakres nostalgii związanej z produktem, który wiąże się z przyjemnymi wspomnieniami; po szóste, zakres trudności związanych z użytkowaniem produktu-jeśli konsument posiada umiejętności wykorzystania wszystkich funkcji produktu, a inni nie posiadają ich, wtedy pojawia się przyjemność z jego użytkowania,

Konsument hedonistyczny, aby zaspokoić potrzebę przyjemności, chce nabywać ciągle nowe produkty, które niekiedy po akcie zakupu marnuje lub niszczy. O konsekwencjach takiego zachowania pisał Barber (2008, s. 246), który wskazał, iż współcześni konsumenci zachowują się jak dzieci, które pożądają coraz to nowych zabawek.

Cechą konsumpcji hedonistycznej jest dokonywanie zakupów pod wpływem impulsów, którymi mogą być między innymi przyjemność związana z aktem zakupu, pozytywne emocje odczuwane podczas zakupów i po nich, opinie innych osób, wystrój i prezentacja produktów w sklepie. Gąsiorowska (2013, s. 9-10) definiuje konsumpcję impulsywną jako zakupy nierefeksyjne, niezamierzone, spontaniczne, związane z nagłą potrzebą kupienia określonego produktu pojawiającą się w sytuacji wystawienia na bodziec, jakim z reguły jest widok samego produktu. Pobudzane są one przez fizyczną bliskość produktu, związane są z niską kontrolą intelektualną oraz z wysoką aktywacją emocjonalną (towarzyszy im podniecenie i stymulacja, przyjemność związana z produktem lub samą sytuacją zakupu). Konsumpcja impulsywna może się przerodzić w zakupoholizm, który polega na uzależnieniu się od zakupów. Uzależnienie to jest swego rodzaju nałogiem związanym z koniecznością 
robienia zakupów. Faber i O’Guinn (1987, s. 132-135) używają terminu kompulsywna konsumpcja na oznaczenie zachowania konsumentów, które jest zazwyczaj nadmierne i ma wyraźnie destrukcyjny wpływ na życie ludzi. Mącik i Mącik (2015, s. 978), analizując zachowania konsumpcyjne grupy Polaków w Wielkiej Brytanii, odkryli, że kompulsywne zachowania w konsumpcji są swoistą strategią zmniejszania napięcia związanego z stresem wynikającym z przebywania na emigracji, co wiąże się z doświadczaniem silniejszego stresu, który wymaga odreagowania.

Symptomem kompulsywnego zachowania jest to, że samo odwiedzanie sklepów sprawia przyjemność konsumentom i daje im poczucie zadowolenia, oraz to, że konsumenci przeżywają pragnienie zakupu, natomiast w mniejszym stopniu interesuje ich przedmiot zakupu (Falkowski, Tyszka, 2001, s. 218).

\section{Konsumpcja etyczna}

W kontekście konsumpcji hedonistycznej związanej z niepohamowanym dążeniem do nabywania dóbr i usług konsumpcyjnych służących zaspokojeniu potrzeb przyjemności pojawia się pytanie o to, czy coś może ograniczyć takie postępowanie ludzi. Wydaje się, iż pomocne w ograniczaniu takiej konsumpcji jest propagowanie zasad i norm etycznych powstrzymujących nadmierną konsumpcję. Jedną z propozycji takich norm etycznych przedstawiła Cortina (2006, s. 96-98), która wykorzystując imperatywy kategoryczne etyki I. Kanta, zbudowała trzy normy etyczne dotyczące konsumpcji, mające charakter powszechnie obowiązujący:

1. Konsumuj tak, aby twoje normy nie były długotrwale niebezpieczne dla natury.

2. Konsumuj tak, abyś jednocześnie wspierał dążenie do wolności każdego człowieka, a także swojej osoby, jak też każdej innej osoby.

3. Przyjmuj normy takiego stylu konsumpcji, który by wspierał twoje dążenie do wolności, jak też każdej innej osoby i umożliwiał zdobywanie bogactwa jako celu życiowego.

Propozycja uniwersalnych reguł etycznych Cortiny jest interesująca, ponieważ zobowiązuje konsumentów do dbania o środowisko naturalne i do nienaruszania wolności i autonomii innych konsumentów poprzez swoją egoistyczną konsumpcję.

Normy i wartości etyczne regulujące zachowania konsumpcyjne stanowią podstawę konsumpcji etycznej. Crane i Matten (2007, s. 341-345) sugerują, że główną istotą koncepcji konsumpcji etycznej jest świadoma i przemyślana decyzja dokony- 
wania pewnych wyborów konsumpcyjnych z powodu osobistych przekonań moralnych i wartości etycznych. Z kolei Doane (2000, s. 6) skupia się w swojej definicji na produkcie, uznając, że etyczny produkt jest związany z jego etycznym wytwarzaniem (zgodnym z prawami człowieka, warunkami pracy, ochroną środowiska itp.), które wpływa na indywidualne wybory konsumenta. Zatem konsumpcja etyczna odnosi się zarówno do etycznych zachowań konsumpcyjnych, jak i do tak zwanych produktów zawierających zawartość etyczną. W pierwszym przypadku do zachowań etycznych można zaliczyć postępowanie, w którym konsument zwraca uwagę na proces wytwarzania danego dobra pod kątem wartości etycznych. Istotny wpływ na to zachowanie mają informacje o nieetycznych zachowaniach producentów. Jak wskazują badania zachowań konsumpcyjnych Creyer i Rossa (1997), konsumenci oczekują od firm zachowania etycznego wobec swoich interesariuszy i są gotowi płacić wyższe ceny za produkty wytworzone w sposób etyczny. Przy czym informacje o etycznych i nieetycznych zachowaniach producentów mają asymetryczny wpływ na postawy konsumentów. Zachowania nieetyczne firm mają negatywny wpływ na decyzje konsumenckie, formą kary jest nienabywanie ich produktów. Natomiast informacje o etycznym zachowaniu się firm nie wpływają wprost na wzrost sprzedaży ich produktów.

W drugim przypadku można mówić o produktach z zawartością etyczną, czyli takich, które nie są tylko fizycznym odzwierciedleniem idei korzyści ekonomicznych, lecz zawierają również pierwiastek etyczny, są „sprawiedliwie” wyprodukowane i biologicznie neutralne wobec środowiska przyrody (Bylok 2013, s. 219-220). Zawartość etyczna dobra konsumpcyjnego wpływa na wybory konsumenckie w sytuacji, kiedy konsumenci biorą pod uwagę moralną stronę dóbr konsumpcyjnych.

Analiza literatury poświęconej etyce konsumpcji pozwala wyróżnić kwestie, który są aktualne w dyskusji o konsumpcji etycznej (rysunek 1). Do najczęściej poruszanych można zaliczyć sprawiedliwy handel (De Pelsmacker, Janssens, 2007), godziwe płace i lepsze warunki pracy w firmach produkujących dobra konsumpcyjne, zanieczyszczenia i odpady pokonsumpcyjne (Shaw, Clarke, 1998), bojkoty konsumenckie (Carrigan, Attalla, 2001), zdrowe jedzenie (z naciskiem na produkty ekologiczne), rozwój społeczny (wspieranie lokalnych dostawców), dobrostan zwierząt i zrównoważony rozwój środowiska (Tallontire, Rentsendorj, Blowfield, 2001). 


\section{Rysunek 1. Formy konsumpcji etycznej}

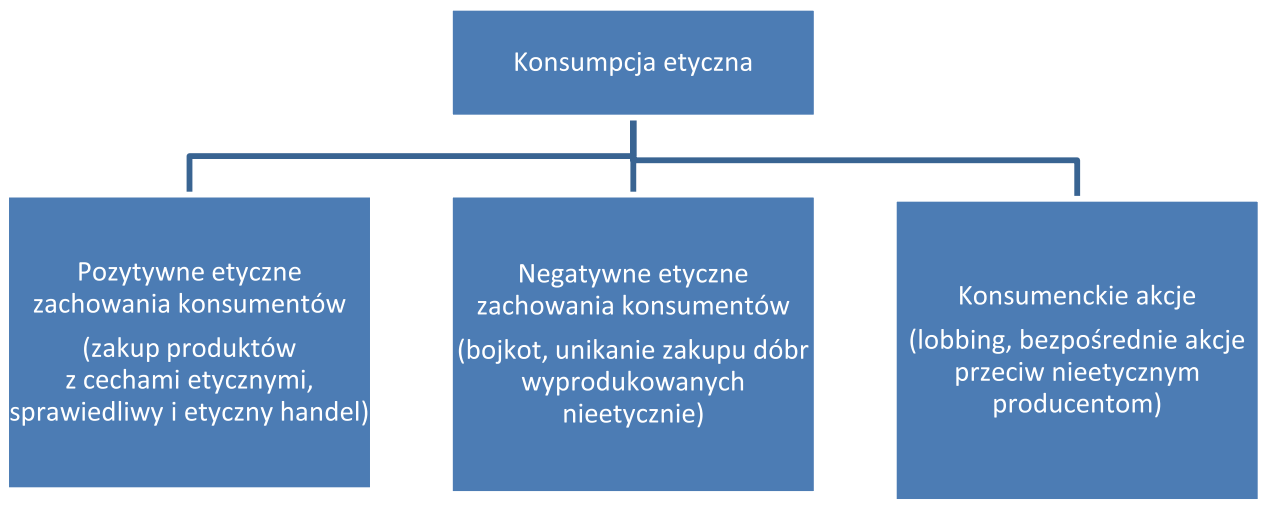

Źródło: opracowanie własne.

W kontekście dyskusji o konsumpcji etycznej dużo uwagi poświęca się kwestii etycznego handlu, który obejmuje sprawiedliwy handel, handel produktami ekologicznymi, handel produktami zrównoważonej gospodarki zasobami, takimi jak etyczne pozyskiwanie zasobów naturalnych (np. lasów, kopalin, energii) i etycznie przetworzone produkty zgodnie z kodeksami etycznego postępowania. Najczęściej w kontekście etycznego handlu poruszana jest kwestia sprawiedliwego handlu, który można ujmować w szerszym i węższym kontekście. W szerokim sensie ,,sprawiedliwy handel" ujmowany jest jako alternatywne podejście do biznesu, którego celem jest zrównoważony rozwój gospodarki polegający na pomocy producentom będącym w niekorzystnej sytuacji i pracownikom w celu poprawy ich warunków życia oraz rozwoju ich rodzin i społeczności poprzez zapewnienie im lepszych warunków prowadzenia handlu (Krier, 2001, s. 9). W węższym rozumieniu pojęcie sprawiedliwy handel obejmuje określone praktyki odnoszące się do przedsiębiorstw wytwarzających produkty, czyli wypłacanie godziwych wynagrodzeń, zapewnienie bezpiecznego i czystego miejsca pracy oraz praktyki uczciwego handlu obejmujące wzmocnienie pozycji rzemieślników, zrównoważony rozwój lokalnej przedsiębiorczości (Littrell, Dickson, 1999, s. 6-12). Sprawiedliwy handel oznacza również kupno produktów pochodzących z krajów rozwijających się jako formę wsparcia ludzi z tych państw. Powstaje pytanie, w jakim stopniu ludzie są zdecydowani nabywać produkty oznaczone jako marki sprawiedliwego handlu (fair-trade). Z badań wynika, że nabywcami produktów oznaczonych jako sprawiedliwe marki są zazwyczaj osoby 
stosunkowo dobrze wykształcone i mające stosunkowo wysokie dochody i wysoki status społeczny (De Pelsmacker, Driesen, Rayp, 2005, s. 363-385). Produkty wytworzone w sposób sprawiedliwy nie są masowo nabywane, ponieważ są droższe od dóbr wyprodukowanych w warunkach określanych jako nieetyczne (zatrudnianie dzieci, niskie płace, brak ochrony bezpieczeństwa pracy itd.). Dla konsumentów mniej zamożnych najważniejsza jest niższa cena, w mniejszym stopniu zwracają oni uwagę na aspekt etyczny. Jak zauważają Carrigan i Attalla (2001, s. 564), konsumenci kupują produkty nieetyczne wtedy, gdy ich cena jest zdecydowanie niższa niż produktów uważanych za etyczne.

Inną formą zachowań charakterystycznych dla konsumpcji etycznej są bojkoty konsumenckie. Polegają one na odmowie kupowania i konsumowania produktów wytwarzanych przez dane przedsiębiorstwo lub państwo. Opierają się na poczuciu solidarności i odpowiedzialności za innych. Bojkot konsumencki może mieć wiele przyczyn. Makarem i Jae (2015) na podstawie badań zapisów na Twitterze zidentyfikowali najczęstsze przyczyny bojkotu, do których zaliczyli nieprzestrzeganie praw człowieka, awarie w przedsiębiorstwach zagrażające środowisku i nadmierny zysk producentów przy jednoczesnym wyzyskiwaniu pracowników. Siła oddziaływania bojkotu konsumenckiego wzrasta, kiedy coraz więcej konsumentów rezygnuje z zakupu produktu wytwarzanego w sposób nieetyczny i staje się to problemem dla producentów. Rozpowszechnianie informacji o bojkotach konsumenckich przez media, w szczególności internet, wpływa na wzrost liczby uczestników protestów przeciwko nieetycznie wytworzonym produktom znanych firm, jak Gap Inc., Nike i Shell. Czynnikiem determinującym podejście do konsumpcji etycznej jest relatywizm moralny tworzący nietrwale i nieprzewidywalne oceny oraz zachowania moralne własne i innych ludzi (Mariański, 2008, s. 219). Konsumenci zamiast zachowywać się etycznie w całym obszarze konsumpcji, wydają się być selektywni etycznie. Wobec różnych produktów i zachowań nieetycznych konsumenci przyjmują odmienne postawy. W przypadku produktów związanych z modą i pozycją społeczną (np. odzieży, obuwia i kosmetyków) wizerunek marki ma pierwszeństwo nad kryteriami etycznymi. Konsumenci nie bojkotują nieetycznych producentów znanych marek, którzy zlecają produkcję swoich produktów do krajów rozwijających, na przykład Bangladeszu, Pakistanu, gdzie pracownicy są wykorzystywani i pracują w warunkach niebezpiecznych dla ich zdrowia. Natomiast w przypadku produktów żywnościowych wytworzonych w sposób nieetyczny (np. stosowanie GMO, nieetyczne zabijanie zwierząt, nieetyczne postępowanie ze zwierzętami, stosowanie antybiotyków) konsumenci w większym zakresie stosują różne formy bojkotu. 


\section{Społecznie odpowiedzialny konsument}

W społeczeństwie konsumpcyjnym oprócz ideologii konsumpcjonizmu opartej na hiperkonsumpcji rozwija się etyczna refleksja nad społecznie odpowiedzialnym zachowaniem konsumentów. Odpowiedzialność w ujęciu etycznym oznacza relację między czynem podmiotu a jego świadomością moralną. Zatem odpowiedzialność konsumentów przejawia się w postaci konsekwencji moralnych za spełniane czyny w sferze konsumpcji. W literaturze można spotkać różne definicje społecznie odpowiedzialnej konsumpcji, na przykład Devinney, Auge i Eckhardt (2006) ujmują społecznie odpowiedzialną konsumpcję jako celowy wybór konsumpcji etycznej na fundamencie osobistych i moralnych przekonań. Obejmuje ona trzy formy działań:

a) gotowość do zaangażowania się w protesty i bojkoty;

b) dokonywanie zakupów produktów z zawartością etyczną i nienabywanie produktów nieetycznych;

c) wyrażanie krytycznych opinii wobec nieetycznych zachowań przedsiębiorstw w ankietach lub innych formach badań rynku.

Z perspektywy etyki konsumpcji za społecznie odpowiedzialnego konsumenta uznać należy osobę odpowiedzialną i społecznie świadomą, której działania na rynku są moralnie uzasadnione i która musi być gotowa zrezygnować ze swoich pragnień konsumpcyjnych. Taki konsument stara się nabywać produkty lub usługi firm uznawanych za odpowiedzialne wobec społecznego i naturalnego środowiska.

Proces kształtowania społecznie odpowiedzialnego konsumenta jest uwarunkowany zmianami w systemach wartości konsumentów, na znaczeniu zyskują wartości etyczne (sprawiedliwość, współodpowiedzialność, poszanowanie innych ludzi, odpowiedzialność za środowisko naturalne). Upowszechnianie tych wartości wpływa na zwiększenie świadomości ekologicznej ludzi. Świadomi konsumenci to tacy, którzy wykazują wrażliwość i „empatię ekologiczną”, mianowicie: nabywają te produkty, których produkcja nie szkodzi środowisku naturalnemu, ograniczają nadmierną konsumpcję, nie powodują nadmiernego zanieczyszczenia środowiska itp. (Mróz, 2008, s. 21 i n.). Czynnikiem wpływającym na kształtowanie się społecznie odpowiedzialnego konsumenta jest świadomość proekologiczna oparta na wartościach etycznych, które pobudzają do większej odpowiedzialności za podejmowane decyzje w sferze konsumpcji. Świadomość ta opiera się na założeniach zrównoważonej konsumpcji opartej na umiarkowanym, oszczędnym korzystania z zasobów naturalnych oraz ekologicznej odpowiedzialności wobec przyszłych pokoleń (Mróz, 2013, s. 172). 
Kształtowanie się świadomości odpowiedzialnego konsumenta możemy podzielić na trzy etapy. W pierwszym konsumenci uświadamiają sobie potrzebę brania pod uwagę wartości etycznych przy podejmowaniu decyzji konsumenckich, ale nie chcą zmieniać swoich przyzwyczajeń związanych z nabywanymi produktami. W drugim etapie konsumenci uświadamiają sobie, iż masowo wytwarzane produkty w konwencjonalny sposób wpływają negatywnie na środowisko naturalne. W związku z tym klienci zmieniają swoje nastawienie wobec produktów na rynku, poszukując takich, które są wytwarzane w warunkach „sprawiedliwych” i w najmniejszym stopniu niszczących środowisko naturalne, na przykład wykorzystujących energię odnawialną przy produkcji. W trzecim etapie rozwoju świadomości odpowiedzialnego konsumowania pojawia się poczucie współodpowiedzialności wobec środowiska naturalnego. Konsument swoją jakość życia buduje w przyjaźni z naturą, z poszanowaniem praw innych uczestników życia społecznego. Przy podejmowaniu decyzji nabywczych bierze pod uwagę kwestie etyczne. Podejmuje aktywne działania na rzecz ochrony środowiska naturalnego, na przykład uczestniczy w ruchach mających na celu przeciwdziałanie niszczeniu środowiska naturalnego. Rozwój świadomości odpowiedzialnego konsumowania jest kluczowym czynnikiem zmian zachowań konsumpcyjnych w kierunku konsumpcji etycznej.

Zachowania społecznie odpowiedzialnego konsumenta w sferze konsumpcji mogą przyjąć różne formy. Po pierwsze - nabywania dóbr konsumpcyjnych, które są wytwarzane w najmniej szkodliwy sposób dla środowiska naturalnego. Po drugie - spożywania tak zwanych dóbr ekologicznych (głównie dotyczy to żywności) bez sztucznych dodatków, konserwantów itp. Po trzecie - nabywania dóbr uznawanych za etyczne, to jest zwracania uwagi na etyczność procesu wytwarzania produktu, na przykład „sprawiedliwie” wytworzona kawa lub produkty wytworzone bez naruszania godności pracowników zatrudnionych przy ich wytworzeniu. Po czwarte - nabywania dóbr, które są wyprodukowane po najniższych kosztach ekologicznych i społecznych, na przykład nabywania środków czystości z małą zawartością niebezpiecznych związków chemicznych, biologicznie neutralne pożywienie dla dzieci. Po piąte - propagowania stylów życia przyjaznych środowisku naturalnemu, na przykład stylu dobrowolnej prostoty w konsumpcji, slow food. Po szóste - propagowania świadomości współodpowiedzialności za zagrożenia wynikające z nadmiernej konsumpcji i nadmiernej produkcji odpadów pokonsumpcyjnych wśród innych konsumentów, na przykład na portalach społecznościowych. Po siódme - aktywnego uczestniczenia w działaniach na rzecz ograniczenia konsumpcji, na przykład w kooperatywach konsumenckich, ruchach proekologicznych. Przedstawiony 
zestaw sposobów działań, jakie mogą podjąć społecznie odpowiedzialni konsumenci, nie jest zamknięty. Jest jedynie propozycją do dalszych dyskusji nad kwestią społecznie odpowiedzialnej konsumpcji w dzisiejszym społeczeństwie.

\section{Podsumowanie}

Refleksja nad relacjami między konsumpcją hedonistyczną i konsumpcją etyczną we współczesnych społeczeństwach skłania do sformułowania kilku wniosków. Po pierwsze, pogłębiona analiza relacji między konsumpcją hedonistyczną a konsumpcją etyczną pozwoliła określić ogólne różnice między nimi, ale również podobieństwa. Trudno jest w jednoznaczny sposób przeciwstawiać konsumpcję hedonistyczną konsumpcji etycznej, ponieważ nabywanie dóbr z zawartością etyczną nie wyklucza doznawania przyjemności z ich konsumowania. W literaturze przedmiotu na określenie takiego zachowania pojawił się termin etyczny hedonizm, który oznacza zakup i konsumpcję produktów z zawartością etyczną. Taki typ hedonizmu może mieć charakter etyczny, jeżeli zachowania konsumpcyjne zaspokajają potrzebę przyjemności konsumentów i nie naruszają praw ani godności innych konsumentów (Szmigin, Carrigan, 2006, s. 610).

Po drugie, konsumpcja etyczna może przybrać formę hedonistyczną związaną z egoistycznym dążeniem do nadmiernego nabywania dóbr konsumpcyjnych, jeśli przerodzi się w hedonistyczny pościg za produktami etycznymi służącymi do osiągania tak zwanego dobrego życia (Adomaviciute, 2013, s. 756).

Po trzecie, zrozumienie i odkrywanie wymiarów przyjemności konsumenta jest ważne dla badania zachowań etycznych w obszarze konsumpcji. Motywy związane z doznawaniem przyjemności nie zawsze stymulują zachowania szkodzące środowisku społecznemu i naturalnemu. Niekiedy wpływają na podejmowanie działań związanych ze społecznie odpowiedzialną konsumpcją. Na przykład ma to miejsce wtedy, gdy konsumenci wytwarzają produkty na własny użytek nie dlatego, że są niedostępne na rynku, ale że sprawia im przyjemność samodzielne zbudowanie konkretnego produktu, na przykład produkowanie mebli, robienie swetrów na drutach, przygotowanie potraw itd. Konsumentom samodzielne wytwarzanie produktów sprawia większą przyjemność niż nabywanie ich w gotowej postaci (Norton, Mochon, Ariely, 2012).

Po czwarte, wśród społecznie odpowiedzialnych konsumentów zachowanie charakterystyczne dla konsumpcji hedonistycznej może wywołać poczucie winy 
wynikające z nabywania produktów wytworzonych w sposób nieetyczny. Poczucie winy jest zwykle rezultatem uznania wartości etycznych i norm moralnych za podstawę ocen zachowania swojego oraz innych i wystąpi w sytuacjach konsumpcyjnych wątpliwie etycznych. Biorąc pod uwagę pojawienie się poczucia winy u konsumenta, jego działania będą zmierzały do wyeliminowania tego poczucia poprzez nienabywanie produktów wątpliwych etycznie (Dedeoglu, Kazancoglu, 2012).

Po piąte, cechą charakteryzującą społecznie odpowiedzialnego konsumenta jest dążenie do umiaru w nabywaniu nowych dóbr i poszukiwaniu oraz spożywaniu produktów, które nie niszczą środowiska naturalnego. Ludzie przejawiający takie postawy za punkt odniesienia przyjmują wartości związane z odpowiedzialnością i sprawiedliwością. Moralność ta wpływa na tworzenie się postawy współodpowiedzialności konsumenta za proces degradacji środowiska naturalnego. Konsumenci mający świadomość szkód, jakie w środowisku naturalnym wywiera nadmierna konsumpcja, zmieniają nawyki konsumpcyjne. Zakres występowania konsumpcji etycznej jest ograniczony - chociaż konsumenci w badaniach deklarują chęć wspierania firm etycznych poprzez nabywanie ich produktów, to jednak kwestie etyczne nie mają większego wpływu na ich rzeczywiste zachowania podczas zakupów, ponieważ wiele produktów o właściwościach etycznych ma wyższą cenę niż konkurencyjne produkty i konsumenci nie chcą ich nabywać. Nawet wśród konsumentów, którzy identyfikują siebie jako konsumenci etyczni, ceny produktów sprawiedliwego handlu mają większe znaczenie niż obawy o etyczność produktów wytwarzanych przez producentów uznawanych za etycznych (Shaw, Clarke, 1999, s. 20). Zakres występowania konsumpcji etycznej zależy od typu społeczeństwa i struktury społecznej. Najczęściej taki typ konsumpcji można spotkać wśród członków społeczeństw wysoko rozwiniętych, przy czym nie we wszystkich klasach i warstwach społecznych, lecz przede wszystkim wśród konsumentów należących do klasy średniej, dobrze wykształconych i osiągających wysokie dochody (Tallontire i in., 2001, s. 16-17).

Po szóste, z uwagi na zagrożenia związane z nadmierną konsumpcją konieczne staje się propagowanie idei konsumpcji etycznej z jej formą społecznie odpowiedzialnej konsumpcji. Idee społecznie odpowiedzialnej konsumpcji powinny być szerzej propagowane przez media i stać się elementem edukacji.

W kontekście rozważań nad upowszechnieniem się konsumpcji etycznej wśród członków społeczeństw wysoko rozwiniętych warto postawić kilka trudnych pytań: Czy jesteśmy naprawdę gotowi poświęcić część swojej konsumpcji, która sprawia nam przyjemność, na rzecz wyższej sprawy, na przykład konsumpcji ekologicznej? Czy społeczna odpowiedzialność konsumpcji to jest coś, co dotyczy kogoś innego, 
a nie mnie osobiście? Jak możemy się przyczynić do ograniczenia występujących zagrożeń środowiska naturalnego bez zmiany naszego stylu życia? Na razie trudno znaleźć jednoznaczną odpowiedź na te pytania, ponieważ większość ludzi nie ma ochoty ograniczyć swojej konsumpcji. Nie chcą ,powrotu do natury”, czyli wyrzeczenia się konsumpcji dóbr zapewniających iluzje szczęścia i krótkotrwałą przyjemność.

Na zakończenie warto wskazać kierunki dalszych badań nad relacjami między konsumpcją hedonistyczną a konsumpcją etyczną. Jednym z nich jest badanie wpływu hedonizmu etycznego na decyzje konsumenckie. Również potrzebne są badania nad rozwojem świadomości społecznie odpowiedzialnej konsumpcji. Kolejnym obszarem badawczym są związki między hedonizmem egoistycznym a hedonizmem etycznym, co pozwoli lepiej poznać i zrozumieć zachowanie współczesnych konsumentów.

\section{Literatura}

Adomaviciute, K. (2013). Relationship Between Utilitarian and Hedonic Consumer Behavior and Socially Responsible Consumption. Economics and Management, 18 (4), 754-760. Alba, J.W., Williams, E.F. (2012). Pleasure Principles: A Review of Research on Hedonic Consumption. Journal of Consumer Psychology. Pobrane z: http://dx.doi.org/10.1016/j. jcps.2012.07.003 (15.01.2016).

Arnold, M.J., Reynolds, K.E. (2003). Hedonic Shopping Motivations. Journal of Retailing, 79, 77-95.

Barber, R.B. (2008). Skonsumowani. Jak rynek psuje dzieci, infantylizuje dorostych i potyka obywateli. Warszawa: Warszawskie Wydawnictwo Literackie MUZA.

Bauman, Z. (2000). Globalizacja. Warszawa: PIW.

Bylok F. (2013). Konsumpcja, konsument i spoteczeństwo konsumpcyjne. Studium socjologiczne. Katowice: Śląsk.

Campbell, C. (1987). The Romantic Ethic and the Spirit of Modern Consumerism. London: Basil Blackwell Publisher.

Carrigan, M., Attalla, A. (2001). The Myth of The Ethical Consumer - Do Ethics Matter in Purchase Behaviour? Journal of Consumer Marketing, 18 (7), 560-578.

Cortina, A. (2006). Ein Ethik des Konsum. Die Bürgerschaft des Verbrauchers in einer globalen Welt. W: P. Koslowski, B.P. Priddat (red.), Ethik des Konsum (s. 31-103). München: Wilhelm Fink Verlag.

Crane, A., Matten, D. (2007). Business Ethics. Oxford: Oxford University Press.

Creyer, E.H., Ross, W.T. (1997). The Influence of Firm Behavior on Purchase Intention: Do Consumers Really Care About Business Ethics? Journal of Consumer Marketing, 14 (6), 421-433. 
De Pelsmacker, P., Driesen, E., Rayp, G. (2005). Do Consumers Care about Ethics? Willingness to Pay for Fair Trade Coffee. Journal of Consumer Affairs, 39 (2), 363-385. Pobrane z: http://onlinelibrary.wiley.com/doi/10.1111/j.17456606.2005.00019.x/full\#b33 (15.01.2016).

Dedeoglu, A.O., Kazancoglu, I. (2012). Consumer Guilt: A Model of Its Antecedents and Consequences. Ege Academic Review, 12 (1), 9-22. Pobrane z: http://www.onlinedergi.com/makaledosyalari/51/pdf2012_1_2.pdf(15.01.2016).

Devinney, T.M., Auge, P., Eckhardt, G. (2006). The Other CSR: Consumer Social Responsibility. Stanford: Social Innovation Review Fall. Pobrane z: http://www.ethicsworld. org/corporatesocialresponsibility/PDF\%20links/theothercsrssir.pdf (20.11.2015).

Doane, D. (2001). Taking Flight: The Rapid Growth of Ethical Consumerism. London: New Economics Foundation.

Faber, R.J., O’Guinn, Th.C. (1987). Compulsive Consumption. Advances in Consumer Research, 14. Pobrane z: www. Acrwebsite.org/rearch/view - proceedings.aspx? $\mathrm{Id}=6670$ (16.01.2016).

Falkowski, A., Tyszka, T. (2001). Psychologia zachowań konsumenckich. Gdańsk: GWP.

Gąsiorowska, A. (2013). Różnice indywidualne w skłonności do kupowania impulsywnego. Konstrukcja i walidacja skali pomiarowej. Psychologia Ekonomiczna, 4, 6-21.

Holbrook, M.B., Hirschaman, E.C. (1982). The Experiential Aspects of Consumption; Consumer Fantasies, Feelings, and Fan, Consumer Fantasies, Feelings, and Fan. Journal of Consumer Research, 9 (2), 132-140. Pobrane z: http://www.jstor.org (16.01.2016).

Krier, J.-M. (2007). Fair Trade 2007: New Facts and Figures From An Ongoing Success Story A Report on Fair Trade in 33 Consumer Countries, DAWS - Dutch Association of Worldshops, Netherlands. Pobrane z: http://www.european-fair-trade-association. org/efta/Doc/FT-E-2007.pdf (15.01.2016).

Littrell, M.A., Dickson, M.A. (1999). Social Responsibility in the Global Market. Fair Trade of Cultural Products. Thousand Oaks, London: Sage Publications.

Mącik, D. (2015). Retail therapy? Style podejmowania decyzji zakupowych Polaków w kraju i na emigracji oraz ich korelaty. Logistyka, 2, 976-983.

Makarem, S.C., Jae, H. (2015). Consumer Boycott Behavior: An Exploratory Analysis of Twitter Feeds. Journal of Consumer Affairs. Pobrane z: http://onlinelibrary.wiley.com/ doi/10.1111/joca.12080/abstract?userIsAuthenticated=false\&deniedAccessCustomise $\mathrm{dMessage}=(16.01 .2016)$.

Mariański, J. (2008). Społeczeństwo i moralność. Studia z katolickiej nauki społecznej i socjologii moralności. Tarnów: Biblios.

Mróz, B. (2008). Zrównoważona konsumpcja jako wyzwanie rozwojowe polskiej gospodarki. W: R. Bartkowiak, J. Ostaszewski (red.), O nowy ład gospodarczy w Polsce (s. 21-30). Warszawa: Oficyna Wydawnicza SGH.

Mróz, B. (2013). Konsument w globalnej gospodarce. Trzy perspektywy. Warszawa: Oficyna Wydawnicza SGH.

Norton, M.I., Mochon, D., Ariely, D. (2012). The IKEA Effect: When Labor Leads To Love. Journal of Consumer Psychology, 22, 453-460. 
Shaw, D., Clarke, I. (1999). Belief Formation in Ethical Consumer Groups: An Exploratory Study. Marketing Intelligence \& Planning, 17 (2/3), 109-119.

Solomon, M.R. (1996). Consumer Behavior Buying, Having, and Being (3rd ed.). Englewood Cliffs N.J.: Prentice-Hall.

Stihler, A. (1998). Die Entstehung des modernen Konsum. Berlin: Verlag Duncker und Humbold.

Stihler, A. (2000). Ausgewählte Konzepte der Sozialpsychologie. W: D. Rosenkranz (red.), Konsum: soziologische, ökonomische und politische Perspektiven (s. 170-183). Opladen: Leske + Budrich.

Szmigin, I., Carrigan, M. (2006). Exploring the Dimensions of Ethical Consumption. European Advances in Consumer Research, 7, 608-613. Pobrane z: http://www.acrwebsite. org/volumes/eacr/vol7/europeanvolume7_25.pdf (25.11.2015).

Tallontire, A., Rentsendorj, E., Blowfield. M. (2001). Ethical Consumers and Ethical TRADE: A Review of Current Literature. Policy Series 12, Natural Resources Institute, University of Greenwich, The University of Greenwich. Pobrane z: http://www. nri.org/projects/publications/policyseries/PolicySeriesNo12.pdf (16.01.2016).

Teller, C., Reutterer, T., Schnedlitz, P. (2008). Hedonic and Utilitarian Shopper Types in Evolved and Created Retail Agglomerations. The International Review of Retail, Distribution and Consumer Research, 18 (3), 283-309.

Urry, J. (2008). Sieci społeczne, podróże i rozmowy. W: P. Sztompka, M. Bogunia-Borowska (red.), Socjologia codzienności (s. 259-285). Kraków: Znak.

Wątroba, W. (2008). Homo postmillenius. Wrocław: Wyd. UE we Wrocławiu.

Weinberg, P. (1986). Erlebnisorienterte Einkaufsstattengestaltung im Einzelhandel. Marketing: Zeitschriftfür Forschung und Praxis, 8, 2, 97-102.

\title{
HEDONISTIC CONSUMPTION AND ETHICAL CONSUMPTION. IS SOCIALLY RESPONSIBLE CONSUMPTION NECESSARY?
}

\begin{abstract}
In the herein paper, the subject of reflection was deemed to be the relations between hedonistic consumption and ethical consumption. The author in question describes the features characteristic of hedonistic consumption, while also indicating that the attractiveness of hedonistic consumption is based on the perception of happiness and pleasure as the ultimate goals of consumption, which should be pursued. The objects that serve the achievement of these goals are consumer goods possessing the charge of pleasure and potential to ensure happiness. In this paper, there is an indication of the spreading of hedonistic attitudes among consumers. Subsequently, the author focuses on presenting the main assumptions of ethical consumption. There is an analysis of its forms and factors determining its occurrence, as
\end{abstract}


well as a reflection on the emergence of a new type of consumer - a socially responsible consumer. Likewise, there is a description of the characteristic features and a presentation of the postulates relating to the morality of a socially responsible consumer.

Translated by Patrick Curran

Keywords: consumption, hedonism, ethical consumption, socially responsible consumption JEL Code: E21 
